\title{
Cyclotheonellazoles A-C, Potent Protease Inhibitors from the Marine Sponge Theonella aff. swinhoei
}

\author{
Michal Issac, ${ }^{\dagger}$ Maurice Aknin, ${ }^{\ddagger}$ Anne Gauvin-Bialecki, ${ }^{\ddagger}$ Nicole De Voogd, ${ }^{\S}$ Alisson Ledoux, ${ }^{\perp}$ (0) \\ Michel Frederich, ${ }^{\perp}$ Yoel Kashman, ${ }^{\dagger}$ and Shmuel Carmeli* ${ }^{\dagger} \oplus$ \\ ${ }^{\dagger}$ School of Chemistry, Raymond and Beverly Sackler Faculty of Exact Sciences, Tel-Aviv University, Ramat Aviv, Tel-Aviv 69978, \\ Israel \\ ${ }^{\ddagger}$ Laboratoire de Chimie des Substances Naturelles et des Aliments, Faculté des Sciences et Technologies, Université de La Réunion, \\ 15 Avenue René Cassin, CS 92 003, 97 744, Saint-Denis, Cedex 9, France \\ ${ }^{\S}$ Naturalis Biodiversity Center, P.O. Box 9517, 2300 RA, Leiden, The Netherlands \\ ${ }^{\perp}$ Laboratory of Pharmacognosy, Department of Pharmacy, CIRM, University of Liège, B36, 4000 Liège, Belgium
}

Supporting Information

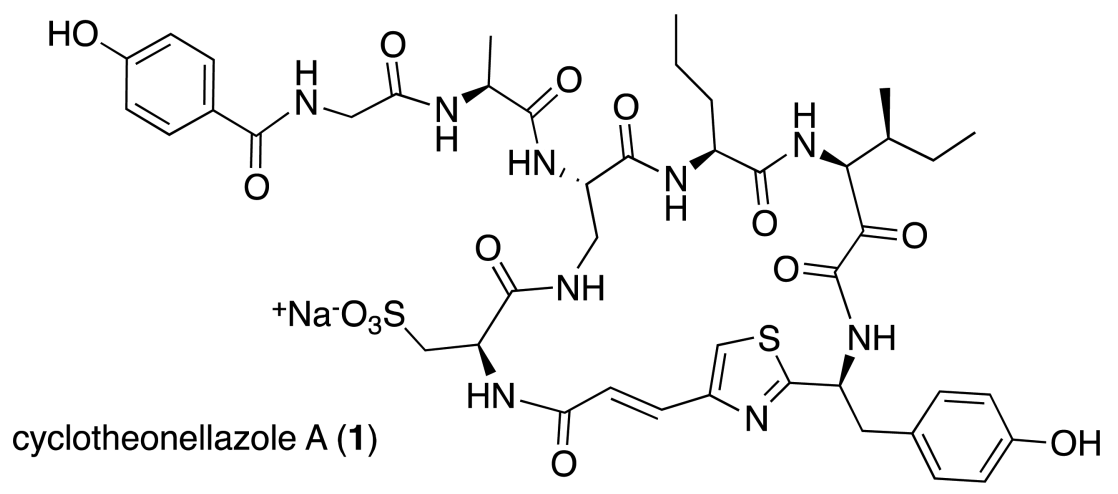

\begin{abstract}
The extract of a sample of the sponge Theonella aff. swinhoei collected in Madagascar exhibited promising in vitro antiplasmodial activity. The antiplasmodial activity was ascribed in part to the known metabolite swinholide A. Further investigation of the extract afforded three unusual cyclic peptides, cyclotheonellazoles A-C ( 1-3), which contain six nonproteinogenic amino acids out of the eight acid units that compose these natural products. Among these acids the most novel were 4-propenoyl-2-tyrosylthiazole and 3-amino-4-methyl-2-oxohexanoic acid. The structure of the compounds was elucidated by interpretation of the 1D and 2D NMR data, HRESIMS, and advanced Merfay's techniques. The new compounds were found to be nanomolar inhibitors of chymotrypsin and sub-nanomolar inhibitors of elastase, but did not present antiplasmodial activity.
\end{abstract}

$\mathrm{M}$ arine sponges of the genus Theonella have been shown to be a rich source of unique bioactive secondary metabolites with diverse structures derived from different biosynthetic pathways such as polyketide macrolides, alkaloids, steroids, and peptides. Among these metabolites are the cytotoxic macrolides swinholides, ${ }^{1}$ which were isolated also from a marine cyanobacterium, ${ }^{2}$ the cyclic peptides cyclotheonamides, ${ }^{3}$ oriamide, ${ }^{4}$ keramamides, ${ }^{5}$ and perthamides, ${ }^{6}$ the linear peptides polytheonamides, ${ }^{7}$ koshikamides, ${ }^{8}$ and yaku'amides, ${ }^{9}$ and the cyclic peptolides theopapuamide, ${ }^{10}$ papuamides, ${ }^{11}$ and callipeltin A. ${ }^{12}$ Most of these metabolites are composed of both proteinogenic and nonproteinogenic amino acids. The latter nonproteinogenic amino acids are primarily derived from amino-acid precursors incorporating an acetate or propionate extender unit. The cyclic peptides cyclotheonamides, ${ }^{3}$ oriamide, ${ }^{4}$ keramamides, ${ }^{5}$ discobahamins, ${ }^{13}$ and calyamides ${ }^{14}$ contain a high proportion of nonproteinogenic amino acids such as vinylogous amino acids, vinylogous thiazole or oxazole amino acids, $\alpha$-keto- $\beta$-amino acids, and oxidized amino acids and are cyclized through diamino acids such as lysine, ornithine, or 2,3-diaminopropionic acid. These metabolites are biosynthesized by hybrid PKS-NRPS enzymes characteristic of bacteria, thus suggesting that symbiotic bacteria, in the sponges, synthesize these metabolites. ${ }^{15}$ In the course of our ongoing research aimed at the isolation of potential biomedicines from marine invertebrates, we examined a sample of the sponge Theonella aff. swinhoei collected in Dos de la Baleine, Madagascar. The extract of the sponge material that exhibited antiplasmodial activity $\left(\mathrm{IC}_{50}=0.30 \mu \mathrm{g} / \mathrm{mL}\right)$ was separated on a Sephadex LH-20 column, and the semipure compounds were separated by reversed-phase HPLC on a $\mathrm{C}_{18}$ preparative column to afford swinholide $\mathrm{A}$, which turned out to be one of the antimalarial constituents $\left(\mathrm{IC}_{50}=4.75 \mu \mathrm{g} / \mathrm{mL}\right)$, and three new cyclic peptides, cyclotheonaellazoles A-C (1- 


\section{Chart 1}
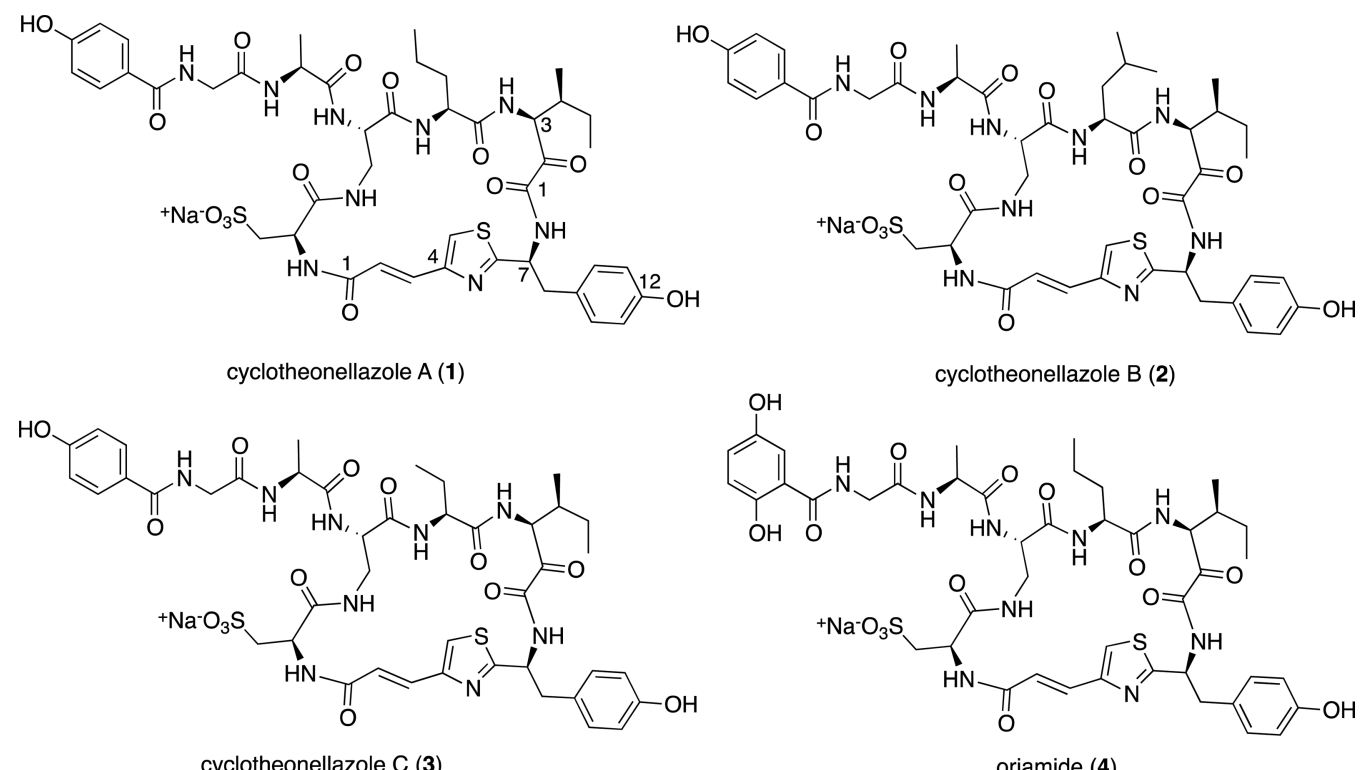

cyclotheonellazole C (3)

oriamide (4)

3). These cyclic peptides were found to contain only two (or three) proteinogenic amino acids, while the rest were nonproteinogenic acids, among them, the unique 4-propenoyl-2-tyrosylthiazole (Ptt), 3-amino-4-methyl-2-oxohexanoic acid (Amoha), and diaminopropionic acid (Dpr). These metabolites are related in structure to oriamide (4), which was isolated a decade ago from a sample of the sponge Theonella sp. collected in Sodwana Bay, South Africa, ${ }^{4}$ but are shown here for the first time to be potent serine protease inhibitors.

\section{RESULTS AND DISCUSSION}

Cyclotheonaellazole A (1) was isolated as an amorphous, colorless solid that presented a positive HRESIMS sodium adduct ion at $m / z 1042.3029$, corresponding to the molecular formula $\mathrm{C}_{44} \mathrm{H}_{54} \mathrm{~N}_{9} \mathrm{Na}_{2} \mathrm{O}_{14} \mathrm{~S}_{2}$ and 22 degrees of unsaturation. The ${ }^{1} \mathrm{H}$ NMR spectrum (in DMSO- $d_{6}$, Table 1) presented 10 exchangeable protons (based on the HSQC experiment), four two-proton doublets of two para-substituted phenols, a thiazole proton, two doublet protons of an isolated and conjugated trans double bond, six methine protons and eight methylene protons between 5.5 and $2.5 \mathrm{ppm}$, a methine proton, six methylene protons, and two doublet- and two triplet-methyl signals in the shielded region of the spectrum. The ${ }^{13} \mathrm{C}$ NMR spectrum (Table 1) exhibited a conjugated carbonyl (198.1 ppm), $12 \mathrm{sp}^{2}$ nonprotonated carbons between 175 and $149 \mathrm{ppm}$, two nonprotonated, three methine, and four doubled methine $\mathrm{sp}^{2}$ carbons between 134 and 114 ppm, six methine and one methylene carbon between 61 and $47 \mathrm{ppm}$, and one methine, six methylene, and four methyl carbons between 43 and 11 ppm. Analysis of the 2D NMR data from the COSY, TOCSY, and HSQC spectra of cyclotheonellazole A (Table 1) allowed the assignment of the side chains of the proteinogenic (glycine and alanine) and nonproteinogenic amino acids (diaminopropionic acid, 2-aminopentanoic acid, and cysteic acid) and the partial assignment of the aromatic residue $p$-hydroxybenzoic acid (Figure 1, bold lines). Furthermore, this analysis established the structure of a modified isoleucine unit with a deshielded amino-methine proton $\left(\delta_{\mathrm{H}} 5.04\right)$ and three isolated spin-systems of the Ptt subunit (Figure 1). HMBC correlations of the $\alpha$ and/or $\beta$ protons of the acid subunits with the amide

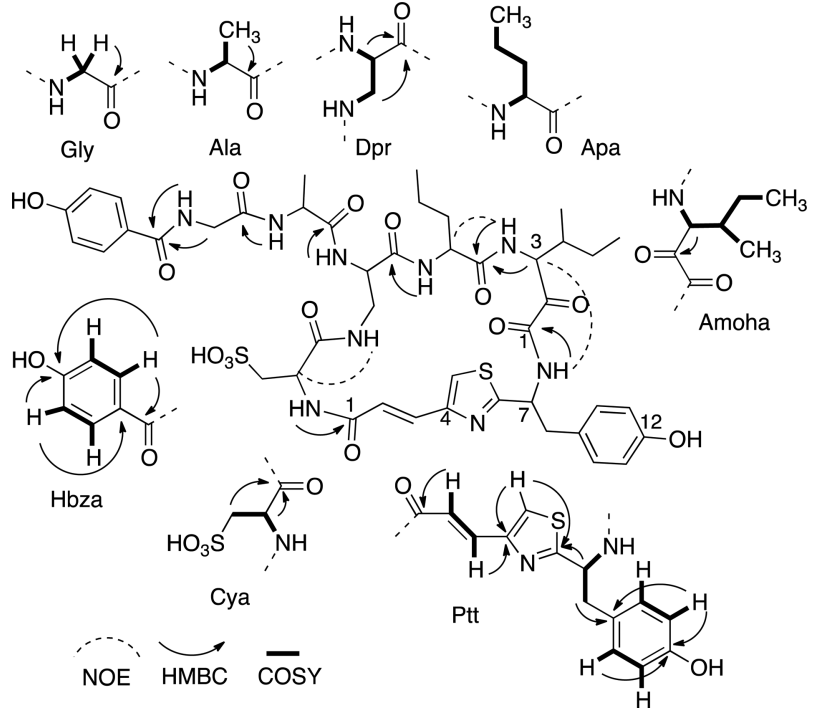

Figure 1. Key COSY, HMBC, and NOE correlations of $\mathbf{1}$.

carboxyl carbons assigned the latter to the side chains of $p$ hydroxybenzoic acid, glycine, alanine, Dpr, and cysteic acid (Cya) (Figure 1). The amide carbonyl of Apa was assigned through the NOE of Amoha-NH with Apa-H-2 and its HMBC correlation with the $\mathrm{sp}^{2}$ carbon resonating at $174.9 \mathrm{ppm}$. The carbonyl and carboxyl of the modified isoleucine moiety (Amoha) were established through the HMBC correlation of Amoha-H-3 with a conjugated carbonyl carbon $\left(\delta_{\mathrm{C}} 198.1\right)$ and combination of an NOE of Amoha-H-3 with Ptt-NH and an HMBC correlation of the latter with the carboxyl carbon resonating at $\delta_{\mathrm{C}} 163.9$, which resembled the chemical shifts of similar 2-oxo-amino acids. ${ }^{4,5}$ The three short proton-spinsystems were assembled to the complete Ptt unit through the HMBC correlations of Ptt-H-2 with the conjugated carbonyl $\left(\delta_{\mathrm{C}} 164.9\right)$, of Ptt-H-3 and the thiazole proton, Ptt-H-5, with the nonprotonated thiazole $\mathrm{sp}^{2}$ carbon $\left(\delta_{\mathrm{C}} 149.7\right)$, of Ptt-H-5 and $\mathrm{H}-7$ with the thiazole nonprotonated carbon $\left(\delta_{\mathrm{C}} 170.7\right)$, of $\mathrm{Ptt}-\mathrm{H}-8 \mathrm{a}, \mathrm{H}-8 \mathrm{~b}$, and $\mathrm{H}-11,11^{\prime}$ with the quaternary $\mathrm{sp}^{2}$ carbon $\left(\delta_{\mathrm{C}}\right.$ 127.6), and of Ptt-H-10,10' and $\mathrm{H}-11,11^{\prime}$ with the phenol 
Table 1. NMR Data (DMSO- $\left.d_{6}\right)$ of Cyclotheonaellazole A $(1)^{a}$

\begin{tabular}{|c|c|c|c|c|}
\hline position & $\delta_{\mathrm{C}}$, type $^{b}$ & $\delta_{\mathrm{H}}(J$ in $\mathrm{Hz})$ & $\mathrm{HMBC}_{\text {correlations }}{ }^{c}$ & NOE correlations ${ }^{d}$ \\
\hline Hbza 1 & 166.3, C & & Hbza-3, Gly-2a,2b,NH & \\
\hline 2 & 124.9, C & & Hbza- $4,4^{\prime}$ & \\
\hline $3,3^{\prime}$ & $129.4, \mathrm{CH}$ & $7.73, \mathrm{~d}(9.0)$ & Hbza-4,4', Gly-NH & Hbza-4,4', Gly-2a,2b,NH, \\
\hline $4,4^{\prime}$ & $115.0, \mathrm{CH}$ & $6.78, \mathrm{~d}(9.0)$ & Hbza-3,3' & Hbza-3,3' \\
\hline 5 & $160.4, \mathrm{C}$ & & Hbza- $3,3^{\prime}, 4,4^{\prime}$ & \\
\hline $5-\mathrm{OH}$ & & 9.96 brs & & \\
\hline \multirow[t]{2}{*}{2} & 42.7, $\mathrm{CH}_{2}$ & 3.79, dd $(16.5,5.5)$ & & Hbza-3,3', Gly-NH, Ala-2,NH \\
\hline & & 3.89, dd $(16.5,5.5)$ & & Hbza-3,3', Gly-NH, Ala-2,NH \\
\hline $\mathrm{NH}$ & & $8.46, \mathrm{t}(5.5)$ & & Hbza-3,3', Gly-2a,2b, Ala-NH \\
\hline Ala 1 & 171.5, C & & Ala-2,3, Dpr- $\alpha-\mathrm{NH}$ & \\
\hline 2 & $47.9, \mathrm{CH}$ & $4.33, \mathrm{~m}$ & Ala-3,NH & Ala-3,NH, Gly-2a,2b, Dpr- $\alpha-\mathrm{NH}$ \\
\hline 3 & $18.6, \mathrm{CH}_{3}$ & $1.16, \mathrm{~d}(7.0)$ & Ala-2,NH & Ala-2,NH, Dpr- $\alpha-\mathrm{NH}$ \\
\hline $\mathrm{NH}$ & & $8.00, \mathrm{~d}(7.5)$ & & Ala-2,3, Gly-2a,2b,NH \\
\hline 2 & 51.1, $\mathrm{CH}$ & $4.03, \mathrm{~m}$ & Dpr- $\alpha-\mathrm{NH}$ & Dpr-3a,3b, $\alpha-\mathrm{NH}, \mathrm{Cya}-2$, Apa-NH \\
\hline \multirow[t]{2}{*}{3} & 40.9, $\mathrm{CH}_{2}$ & $2.49, \mathrm{~m}$ & Dpr- $\alpha-\mathrm{NH}$ & $\mathrm{Dpr}-2,3 \mathrm{~b}, \alpha-\mathrm{NH}, \beta-\mathrm{NH}$ \\
\hline & & $3.75, \mathrm{~m}$ & & Dpr-2,3a, $\beta-\mathrm{NH}$ \\
\hline$\alpha-\mathrm{NH}$ & & $7.93, \mathrm{~d}(7.5)$ & & Dpr-2,3a,3b, Ala-2,3 \\
\hline$\beta$-NH & & 7.85, brs & & Dpr-3a, Cya-NH, Apa-NH \\
\hline Apa 1 & 174.9, C & & Amoha-3,NH & \\
\hline 2 & $54.5, \mathrm{CH}$ & $4.32, \mathrm{~m}$ & & Apa-3a,3b,4a,4b,NH, Amoha-NH \\
\hline \multirow[t]{2}{*}{3} & $32.3, \mathrm{CH}_{2}$ & $1.63, \mathrm{~m}$ & Apa-4b,5,NH & Apa-2,3b,4a,5,NH \\
\hline & & $2.29, \mathrm{~m}$ & & Apa-2,3a,4a,4b,5,NH \\
\hline \multirow[t]{2}{*}{4} & $19.8, \mathrm{CH}_{2}$ & $1.31, \mathrm{~m}$ & Apa-5 & Apa-2,3a,3b,5 \\
\hline & & $1.53, \mathrm{~m}$ & & Apa-2,3b,5,NH \\
\hline 5 & 13.9, $\mathrm{CH}_{3}$ & $0.92, \mathrm{t}(7.0)$ & Apa-4a,4b & Apa-3b,4a,4b,NH, Amoha-4 \\
\hline $\mathrm{NH}$ & & $8.61, \mathrm{~d}(7.0)$ & & Apa-2,3b,4b,5, Dpr- $2, \beta-\mathrm{NH}$ \\
\hline Amoha 1 & $163.9, \mathrm{C}$ & & Ptt-NH & \\
\hline 3 & $60.2, \mathrm{CH}$ & 5.04, dd $(9.5,3.5)$ & Amoha-5,NH & Amoha-4,5,NH, Ptt-2,NH \\
\hline 4 & $37.1, \mathrm{CH}$ & 2.39, m & Amoha-3,5,6b,7 & Amoha-2,3,5,NH, Apa-5 \\
\hline 5 & $16.3, \mathrm{CH}_{3}$ & $0.77, \mathrm{~d}(7.0)$ & Amoha-3,6a,6b & Amoha-3,4,6a,6b \\
\hline \multirow[t]{2}{*}{6} & 23.4, $\mathrm{CH}_{2}$ & $1.08, \mathrm{~m}$ & Amoha-5,7 & Amoha-5,7,NH \\
\hline & & $1.14, \mathrm{~m}$ & & Amoha-5,7 \\
\hline 7 & 11.9, $\mathrm{CH}_{3}$ & $0.72, \mathrm{t}(7.5)$ & Amoha-6a,6b & Amoha-6a,6b \\
\hline $\mathrm{NH}$ & & $8.31, \mathrm{~d}(9.5)$ & & Amoha-3,4, Apa-2 \\
\hline Ptt 1 & 164.9, C & & Ptt-2,3, Cya-NH & \\
\hline 2 & $123.6, \mathrm{CH}$ & $6.76, \mathrm{~d}(15.0)$ & Ptt-3 & Ptt-3, Amoha-3, Cya-NH \\
\hline 3 & $132.6, \mathrm{CH}$ & $7.39, \mathrm{~d}(15.0)$ & Ptt-2,5 & Ptt-2,5, Cya-NH \\
\hline 4 & 149.7, C & & Ptt-2,3,5 & \\
\hline 5 & $123.3, \mathrm{CH}$ & $7.85, \mathrm{~s}$ & & Ptt-3 \\
\hline 6 & 170.7, C & & Ptt-5,7,8a,8b & \\
\hline 7 & $54.6, \mathrm{CH}$ & $5.21, \mathrm{~m}$ & Ptt- $8 \mathrm{a}, 8 \mathrm{~b}$ & Ptt- $8 \mathrm{a}, 8 \mathrm{~b}, 10,10^{\prime}, \mathrm{NH}$ \\
\hline \multirow[t]{2}{*}{8} & $39.2, \mathrm{CH}_{2}$ & $3.02, \mathrm{dd}(14.0,5.5)$ & Ptt-7,10,10' & Ptt-7,10,10', NH \\
\hline & & 3.10, dd $(14.0,4.0)$ & & Ptt-7,10,10', NH \\
\hline 9 & 127.6, C & & Ptt-7,8a,8b,11,11' & \\
\hline $10,10^{\prime}$ & $130.6, \mathrm{CH}$ & $7.17, \mathrm{~d}(8.5)$ & Ptt- $8 \mathrm{a}, 8 \mathrm{~b}$ & Ptt-7,8a,8b,11,11',NH \\
\hline $11,11^{\prime}$ & $115.3, \mathrm{CH}$ & $6.68, \mathrm{~d}(8.5)$ & Ptt-10,10',12-OH & Ptt-10,10', NH,12-OH \\
\hline 12 & 156.3, C & & 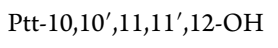 & \\
\hline $12-\mathrm{OH}$ & & $9.27, \mathrm{~s}$ & & Ptt-11,11 \\
\hline $\mathrm{NH}$ & & $9.40, \mathrm{~d}(8.0)$ & & 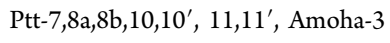 \\
\hline Cya 1 & $170.7, \mathrm{C}$ & & Сya-2,3a,3b & \\
\hline 2 & $49.5, \mathrm{CH}$ & $4.74, \mathrm{~m}$ & Cya-3a & Dpr-2, Cya-3a,3b,NH \\
\hline \multirow[t]{2}{*}{3} & $50.6, \mathrm{CH}_{2}$ & 2.70, dd $(14.0,6.0)$ & Cya-2 & Cya-2,3b \\
\hline & & $3.25, \mathrm{~m}$ & & Cya-2,3a \\
\hline $\mathrm{NH}$ & & $8.16, \mathrm{~d}(9.0)$ & & Dpr- $\beta-\mathrm{NH}, \mathrm{Ptt}-2,3$ \\
\hline
\end{tabular}

${ }^{a_{5}} 50 \mathrm{MHz}$ for ${ }^{1} \mathrm{H}, 100 \mathrm{MHz}$ for ${ }^{13} \mathrm{C} .{ }^{b}$ Multiplicity and assignment from HSQC experiment. ${ }^{c}$ Determined from HMBC experiment, ${ }^{n} J_{\mathrm{CH}}=8 \mathrm{~Hz}$, recycle time $1 \mathrm{~s}$, from carbon(s) stated to the indicated proton $(\mathrm{s}) .{ }^{d}$ Selected NOEs from ROESY experiment. 
Table 2. NMR Data (DMSO- $\left.d_{6}\right)$ of Cyclotheonaellazoles B (2) and C (3)

\begin{tabular}{|c|c|c|c|c|}
\hline \multirow[b]{2}{*}{ position } & \multicolumn{2}{|c|}{ cyclotheonaellazole B (2) } & \multicolumn{2}{|c|}{ cyclotheonaellazole C (3) } \\
\hline & $\delta_{\mathrm{C}}$, type $^{b}$ & $\delta_{\mathrm{H}}(\mathrm{J}$ in $\mathrm{Hz})$ & $\delta_{\mathrm{C}}$, type $^{b}$ & $\delta_{\mathrm{H}}(J$ in $\mathrm{Hz})$ \\
\hline Hbza 1 & 166.3, C & & 166.4, C & \\
\hline 2 & 124.9, C & & 124.9, C & \\
\hline $3,3^{\prime}$ & $129.4, \mathrm{CH}$ & $7.72, \mathrm{~d}(8.5)$ & 129.4, $\mathrm{CH}$ & $7.73, \mathrm{~d}(8.5)$ \\
\hline $4,4^{\prime}$ & 115.0, $\mathrm{CH}$ & $6.78, \mathrm{~d}(8.5)$ & 114.9, $\mathrm{CH}$ & $6.78, \mathrm{~d}(8.5)$ \\
\hline 5 & $160.4, \mathrm{C}$ & & $160.4, \mathrm{C}$ & \\
\hline $5-\mathrm{OH}$ & & $9.97 \mathrm{brs}$ & & 9.95 brs \\
\hline Gly 1 & 168.9, C & & $168.9, \mathrm{C}$ & \\
\hline \multirow[t]{2}{*}{2} & $42.7, \mathrm{CH}_{2}$ & 3.78 , dd $(16.0,6.0)$ & $42.7, \mathrm{CH}_{2}$ & $3.78, \mathrm{~m}$ \\
\hline & & 3.88 , dd $(16.0,6.0)$ & & $3.89, \mathrm{~m}$ \\
\hline $\mathrm{NH}$ & & $8.45, \mathrm{t}(6.0)$ & & $8.46, \mathrm{t}(5.5)$ \\
\hline Ala 1 & 172.1, C & & 171.5, C & \\
\hline 2 & $48.5, \mathrm{CH}$ & 4.33 , dq $(7.5,7.0)$ & 47.7, $\mathrm{CH}$ & $4.33, \mathrm{dq}(7.5,7.0)$ \\
\hline 3 & 19.2, $\mathrm{CH}_{3}$ & $1.15, \mathrm{~d}(7.0)$ & $18.5, \mathrm{CH}_{3}$ & $1.16, \mathrm{~d}(7.0)$ \\
\hline $\mathrm{NH}$ & & $8.01, \mathrm{~d}(7.5)$ & & $8.00, \mathrm{~d}(7.5)$ \\
\hline Dpr 1 & 171.2, C & & 171.4, C & \\
\hline 2 & $51.2, \mathrm{CH}$ & $4.01, \mathrm{~m}$ & $51.1, \mathrm{CH}$ & 4.03, m \\
\hline \multirow[t]{2}{*}{3} & 41.0, $\mathrm{CH}_{2}$ & $2.45, \mathrm{~m}$ & 40.6, $\mathrm{CH}_{2}$ & 2.46, m \\
\hline & & $3.76, \mathrm{~m}$ & & 3.77, m \\
\hline$\alpha-\mathrm{NH}$ & & $7.90, \mathrm{~d}(7.5)$ & & $7.94, \mathrm{~d}(7.5)$ \\
\hline$\beta$-NH & & 7.84, brs & & 7.83, brs \\
\hline Leu/hAla 1 & 175.2, C & & 174.8, C & \\
\hline 2 & $52.7, \mathrm{CH}$ & $4.40, \mathrm{~m}$ & $55.9, \mathrm{CH}$ & $4.27, \mathrm{~m}$ \\
\hline \multirow[t]{2}{*}{3} & 38.2, $\mathrm{CH}_{2}$ & $1.26, \mathrm{~m}$ & 23.3, $\mathrm{CH}_{2}$ & $1.78, \mathrm{~m}$ \\
\hline & & $2.38, \mathrm{~m}$ & & $2.19, \mathrm{~m}$ \\
\hline 4 & $24.4, \mathrm{CH}$ & $1.79, \mathrm{~m}$ & 11.7, $\mathrm{CH}_{3}$ & $0.99, \mathrm{t}(7.0)$ \\
\hline 5 & 11.7, $\mathrm{CH}_{3}$ & $0.92, \mathrm{~d}(6.5)$ & & \\
\hline 6 & 11.7, $\mathrm{CH}_{3}$ & $0.88, \mathrm{~d}(6.5)$ & & \\
\hline $\mathrm{NH}$ & & $8.58, \mathrm{~d}(7.0)$ & & $8.61, \mathrm{~d}(7.5)$ \\
\hline Amoha 1 & 164.1, C & & 163.9, C & \\
\hline 2 & 198.9, C & & 198.1, C & \\
\hline 3 & $60.4, \mathrm{CH}$ & $5.05, \mathrm{dd}(9.5,3.5)$ & $60.2, \mathrm{CH}$ & $5.04, \mathrm{~m}$ \\
\hline 4 & 38.1, CH & $2.39, \mathrm{~m}$ & 37.1, CH & $2.39, \mathrm{~m}$ \\
\hline 5 & 16.2, $\mathrm{CH}_{3}$ & $0.76, \mathrm{~d}(6.5)$ & 16.3, $\mathrm{CH}_{3}$ & $0.77, \mathrm{~d}(6.5)$ \\
\hline \multirow[t]{2}{*}{6} & 23.5, $\mathrm{CH}_{2}$ & $1.07, \mathrm{~m}$ & 23.4, $\mathrm{CH}_{2}$ & $1.08, \mathrm{~m}$ \\
\hline & & $1.15, \mathrm{~m}$ & & $1.14, \mathrm{~m}$ \\
\hline 7 & 11.9, $\mathrm{CH}_{3}$ & $0.71, \mathrm{t}(7.5)$ & 11.9, $\mathrm{CH}_{3}$ & $0.72, \mathrm{t}(7.5)$ \\
\hline NH & & $8.36, \mathrm{~d}(9.5)$ & & $8.32, \mathrm{~d}(9.5)$ \\
\hline Ptt 1 & 165.0, C & & 165.0, C & \\
\hline 2 & 123.6, $\mathrm{CH}$ & $6.76, \mathrm{~d}(15.0)$ & 123.5, $\mathrm{CH}$ & 6.76, m \\
\hline 3 & 132.6, $\mathrm{CH}$ & $7.38, \mathrm{~d}(15.0)$ & $132.7, \mathrm{CH}$ & $7.39, \mathrm{~d}(15.0)$ \\
\hline 4 & 149.7, C & & 149.7, C & \\
\hline 5 & $123.2, \mathrm{CH}$ & 7.84 , brs & 123.3, CH & 7.85, brs \\
\hline 6 & $170.8, \mathrm{C}$ & & $170.7, \mathrm{C}$ & \\
\hline 7 & $54.6, \mathrm{CH}$ & $5.20, \mathrm{q}(7.5)$ & $54.5, \mathrm{CH}$ & $5.21, \mathrm{~m}$ \\
\hline \multirow[t]{2}{*}{8} & 39.1, $\mathrm{CH}_{2}$ & $3.01, \mathrm{~m}$ & $39.2, \mathrm{CH}_{2}$ & $3.02, \mathrm{dd}(14.0,6.0)$ \\
\hline & & $3.08, \mathrm{~m}$ & & $3.09, \mathrm{~m}$ \\
\hline 9 & 127.6, C & & 127.6, C & \\
\hline $10,10^{\prime}$ & 130.6, $\mathrm{CH}$ & $7.16, \mathrm{~d}(8.0)$ & 130.6, CH & $7.16, \mathrm{~d}(8.5)$ \\
\hline $11,11^{\prime}$ & $115.3, \mathrm{CH}$ & $6.67, \mathrm{~d}(8.0)$ & $115.3, \mathrm{CH}$ & $6.68, \mathrm{~d}(8.5)$ \\
\hline 12 & 156.3, C & & 156.3, C & \\
\hline $12-\mathrm{OH}$ & & $9.27, \mathrm{~s}$ & & $9.26, \mathrm{~s}$ \\
\hline NH & & $9.39, \mathrm{~d}(8.0)$ & & $9.40, \mathrm{~d}(8.0)$ \\
\hline Суa 1 & 170.9, C & & $170.7, \mathrm{C}$ & \\
\hline 2 & $49.5, \mathrm{CH}$ & $4.73, \mathrm{~m}$ & $49.5, \mathrm{CH}$ & $4.74, \mathrm{~m}$ \\
\hline \multirow[t]{2}{*}{3} & $50.7, \mathrm{CH}_{2}$ & $2.68, \mathrm{dd}(13.5,5.5)$ & 50.7, $\mathrm{CH}_{2}$ & $2.70, \mathrm{dd}(14.0,6.0)$ \\
\hline & & $3.25, \mathrm{~m}$ & & $3.25, \mathrm{~m}$ \\
\hline NH & & & & $8.15, \mathrm{~d}(9.5)$ \\
\hline
\end{tabular}

${ }^{a} 500 \mathrm{MHz}$ for ${ }^{1} \mathrm{H}, 100 \mathrm{MHz}$ for ${ }^{13} \mathrm{C} .{ }^{b}$ Multiplicity and assignment from HSQC experiment. 
carbon $\left(\delta_{\mathrm{C}} 156.3\right)$. These eight subunits were assembled to the full planar structure of $\mathbf{1}$ based on the HMBC correlations of the $p$-hydroxybenzyl amide carbonyl with the $\mathrm{NH}$ of Gly, the amide carbonyl of Gly with the $\mathrm{NH}$ of Ala, the amide carbonyl of Ala with the $\alpha-\mathrm{NH}$ of Dpr, the amide carbonyl of Dpr with the $\mathrm{NH}$ of Apa, the amide carbonyl of Apa with the $\mathrm{NH}$ of Amoha, the amide carbonyl of Amoha with the NH of Ptt, the amide carbonyl of Ptt with the $\mathrm{NH}$ of Cya, and the amide carbonyl of Cya with the $\beta$-NH of Dpr and the NOEs of Apa$\mathrm{H}-2$ with Amoha-NH and Amoha-H-3 with Ptt-NH (Figure 1). These correlations were further supported by additional NOE correlations (Table 1).

The absolute configurations of the stereogenic centers of the amino acids in $\mathbf{1}$ were determined by a variant of the advanced Marfey's method. ${ }^{16}$ Treatment of 1 with $\mathrm{H}_{2} \mathrm{O}_{2} / \mathrm{NaOH}^{17}$ followed by acid hydrolysis afforded a mixture of the amino acids derived from 1 where the Amoha was converted to Ile. The sample was split into two portions; one reacted with LFDAA and the other with D-FDAA. Analysis of the derivatized mixture of amino acids by LC-MS revealed that the Ala, Dpr, Apa, Amoha, Cya, and Ptt are of the L-form. An attempt to treat the cyclic peptide with ozone prior to the hydrolysis failed and did not produce any recognized amino acid. The absolute $S$ configuration of C-4 of Amoha was determined by comparison of the ${ }^{13} \mathrm{C}$ chemical shifts of the methyl signals in Amoha (C-5, $16.3 \mathrm{ppm}$, and C-7, $11.9 \mathrm{ppm}$ ) with those of L-Ile (C-5, 16.2 ppm, and C-6, $11.6 \mathrm{ppm})$ in micropeptin DR1056, ${ }^{18}$ L-allo-Ile (C-5, $14.1 \mathrm{ppm}$, and C-7, $12.2 \mathrm{ppm}$ ) in micropeptin KT1042, ${ }^{19}$ and D-allo-Ile (C-5, $13.8 \mathrm{ppm}$, and C-6, $12.0 \mathrm{ppm}$ ) in aeruginosin GE686. ${ }^{20}$ On the basis of these arguments structure $\mathbf{1}$ is proposed for cyclotheonellazole A.

The structure elucidation of cyclotheonellazoles B (2) and C (3) was accomplished in a similar manner. Both shared the same basic structure with 1 , in which leucine (in 2) and homoalanine (in 3) replaced the 2-aminopentanoic acid of cyclotheonellazole A (1). Cyclotheonellazole B (2) presented an HRESIMS protonated molecule at $\mathrm{m} / z 1034.3363$ corresponding to the molecular formula $\mathrm{C}_{45} \mathrm{H}_{57} \mathrm{~N}_{9} \mathrm{NaO}_{14} \mathrm{~S}_{2}$ and 22 degrees of unsaturation. Its NMR data (DMSO- $d_{6}$, Table 2) were similar to those of $\mathbf{1}$, presenting, in the ${ }^{1} \mathrm{H}$ NMR spectrum, two doublet methyl signals $\left(\delta_{\mathrm{H}} 0.88\right.$ and 0.92$)$ and an isopropyl-methine proton $\left(\delta_{\mathrm{H}} 1.79\right)$ instead of the triplet methyl signal and the diastereotopic methylene signals $\left(\delta_{\mathrm{H}}\right.$ $1.53,1.31$ ) of Apa in $\mathbf{1}$. In the ${ }^{13} \mathrm{C}$ NMR spectrum of 2 (Table $2)$, two new methyl carbons $\left(\delta_{\mathrm{C}} 23.6\right.$ and 21.0) and a methine carbon $\left(\delta_{\mathrm{C}} 24.4\right)$ appear instead of the methyl and methylene signals ( $\delta_{\mathrm{C}} 13.9$ and 19.8 , respectively) of Apa in 1. Interpretation of the 2D NMR data collected for 2 (Table 2) revealed that the two doublet methyl groups $\left(\delta_{\mathrm{H}} 0.88\right.$ and 0.92 , $\delta_{\mathrm{C}} 23.6$ and 21.0, respectively) were coupled to a methine $\left(\delta_{\mathrm{H}}\right.$ $\left.1.79, \delta_{\mathrm{C}} 24.4\right)$, which in turn was coupled to a methylene $\left(\delta_{\mathrm{H}}\right.$ $\left.2.38,1.26, \delta_{\mathrm{C}} 38.2\right)$. The latter methylene was coupled to an $\alpha$ methine of an amino acid $\left(\delta_{\mathrm{H}} 4.40, \delta_{\mathrm{C}} 52.7\right)$, which was coupled through a COSY correlation to an amide proton $\left(\delta_{\mathrm{H}}\right.$ 8.58). HMBC correlation of the $\alpha$-methine $\left(\delta_{\mathrm{H}} 4.40\right)$ with an amide carbonyl carbon $\left(\delta_{\mathrm{C}} 175.2\right)$ established this amino acid as Leu. This assignment revealed that the Apa, in $\mathbf{1}$, was substituted by a Leu, in 2 , while the rest of the molecule remained identical. The configurations of the stereogenic centers of the amino acids of $\mathbf{2}$ were established by a modified Marfey's method, ${ }^{16,17,21}$ in which the retention times of the LFDAA-derivatized mixture of amino acids from 2 were compared with those from 1 (correlated on the basis of their retention times and molecular MS ions) and by comparison with the retention times of L-FDAA-derivatized D,L-leucine. This procedure established all amino acids as of the L-form. On the basis of these arguments the structure of cyclotheonellazole B was established as 2 .
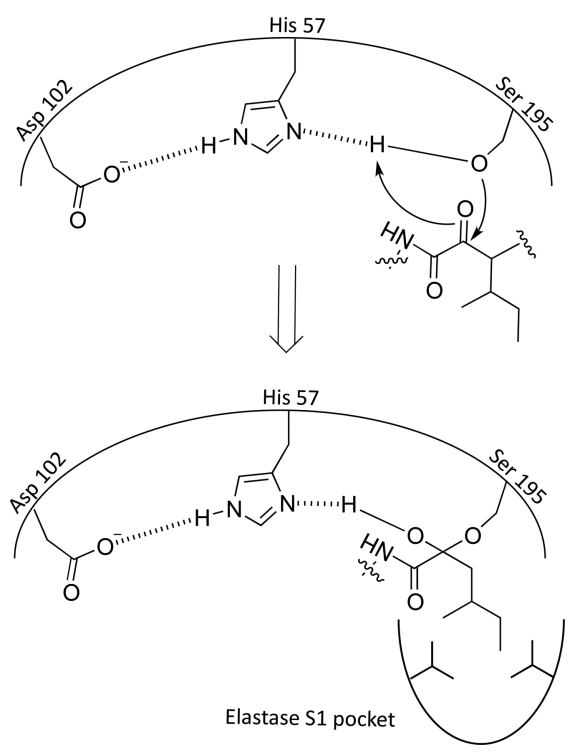

Figure 2. Schematic illustration of elastase inhibition mechanism.

Cyclotheonellazole C (3) presented a positive HRESIMS sodium adduct ion at $\mathrm{m} / z 1028.2869$ corresponding to the molecular formula $\mathrm{C}_{43} \mathrm{H}_{52} \mathrm{~N}_{9} \mathrm{Na}_{2} \mathrm{O}_{14} \mathrm{~S}_{2}$ and 22 degrees of unsaturation. These findings suggested that 3 contains one methylene less than 1 . The NMR data of 3 (DMSO- $d_{6}$, Table 2) were almost identical with those of $\mathbf{1}$. Small differences in the chemical shifts of the proton and carbon signals of the straight-chain nonproteogenic amino acid (Apa in 1) and the absence of one methylene (in 3 relatives to 1 ) were the only differences observed, when the NMR spectra of 1 and 3 were compared, identifying the amino acid as homoalanine. The structure of the homoalanine and the full structure of 3 were established unambiguously by the $2 \mathrm{D}$ NMR experiments summarized in Table 2. The configurations of the amino acids of 3 were established by a similar procedure to the one used for 2 and by comparison with L-FDAA-derivatized D,Lhomoalanine. ${ }^{16,17,21}$ This analysis established that all of the amino acids of cyclotheonellazole $\mathrm{C}$ are of the $\mathrm{L}$-form, thus assigning its structure as 3 .

The biological activities of these compounds were tested against the serine protease enzymes chymotrypsin and elastase and the malaria parasite Plasmodium falciparum. Cyclotheonellazoles A (1), B (2), and C (3) were inactive against P. falciparum ( $\mathrm{IC}_{50}$ 's $>20 \mu \mathrm{g} / \mathrm{mL}$ ). Cyclotheonellazoles A (1), $\mathrm{B}$ (2), and C (3) inhibited chymotrypsin with $\mathrm{IC}_{50}$ values of $0.62,2.8$, and $2.3 \mathrm{nM}$, respectively, and elastase with $\mathrm{IC}_{50}$ values of $0.034,0.10$, and $0.099 \mathrm{nM}$, respectively. On the basis of the $\mathrm{X}$-ray structure of the trypsin-cyclotheonamide A complex that supports the formation of a covalent tetrahedral hemiketal between the $\alpha$-ketoamide of cyclotheonamide A and Ser195 of trypsin, $^{22}$ one can assume that the cyclotheonellazole complexes with elastase (and similarly with chymotrypsin) exhibit a tetrahedral transition state involving the keto group of Amoha and Ser195 of elastase, while the side chain of Amoha fits in the enzyme $S 1$ pocket. $^{23}$ The negatively charged oxygen 
is probably stabilized through a hydrogen bond with the His57 residue in the enzyme, and the cleavage cannot occur because carbon is a poor leaving group (Figure 2). The $\mathrm{IC}_{50}$ values obtained for the inhibition of chymotrypsin and elastase by the cyclotheonellazoles illuminated some structure-activity relationships. Cyclotheonellazole A, which contains a 2-aminopentanoic acid residue, was found to be the most potent inhibitor. This is probably due to a better compatibility with the enzyme S2 subsite. Cyclotheonellazoles B and C contain the amino acids leucine and homoalanine, and it seems that the length and the branching of the aliphatic chain influence the activity.

In summary, we have isolated three new cyclic peptides, along with the known dimeric polyketide swinholide A, from a $T$. aff. swinhoei sponge collected in Madagascar. Cyclotheonellazoles $\mathrm{A}-\mathrm{C}(\mathbf{1}-\mathbf{3})$ are composed of a high proportion of nonproteinogenic amino acids and are related in structure to oriamide (4), which was isolated a decade ago from a sample of the sponge Theonella sp. collected in Sodwana Bay, South Africa. ${ }^{4}$ These cyclic peptides are shown here for the first time to be potent elastase and chymotrypsin inhibitors. The newly isolated cyclotheonellazoles A-C further validate Piel's group's findings concerning the huge diversity of hybrid PKS-NRPS enzymes, characteristic of bacteria, found in T. swinhoei. ${ }^{15}$ These compounds, which are presumably biosynthesized by such hybrid enzymes, append to the constantly growing list of "nonribosomally" biosynthesized cyclic peptides isolated from T. swinhoei. The context of the biosynthesis of these highly active protease inhibitors within the sponge is yet unknown, but they provide us with additional scaffolds that selectively inhibit homologous serine proteases of pharmaceutical significance.

\section{EXPERIMENTAL SECTION}

General Experimental Procedures. Optical rotation values were obtained on a Jasco P-1010 polarimeter at the sodium D line (589 $\mathrm{nm}$ ). UV spectra were recorded on an Agilent 8453 spectrophotometer. IR spectra were recorded on a Bruker Tensor 27 FT-IR instrument (Billerica, MA, USA). NMR spectra were recorded on Bruker Avance and Avance III spectrometers at $500.13 \mathrm{MHz}$ for ${ }^{1} \mathrm{H}$ and $125.76 \mathrm{MHz}$ for ${ }^{13} \mathrm{C}$. DEPT, COSY-45, gTOCSY, gROESY, gHSQC, gHMQC, and gHMBC spectra were recorded using standard Bruker pulse sequences. NMR chemical shifts were referenced to tetramethylsilane, $\delta_{\mathrm{H}}$ and $\delta_{\mathrm{C}}=0 \mathrm{ppm}$. High-resolution mass spectra were recorded on a Waters MaldiSynapt instrument (ESI), and LCMS spectra were recorded on a Waters Xevo TQD instrument (ESI). HPLC separations were performed on a Merck Hitachi HPLC system (L-6200 Intelligent pump and L-4200 UV-vis detector), a JASCO P42080 Plus HPLC system with a multiwavelength detector, and an Agilent 1100 Series HPLC system.

Biological Material. The sponge Theonella aff. swinhoei (BA-019) was collected in Dos de la Baleine $\left(22^{\circ} 14.857 \mathrm{~S}, 43^{\circ} 10.892 \mathrm{E}\right)$, Madagascar, at a depth of $28 \mathrm{~m}$ on December 2011. A voucher specimen (RMNH POR 7396) was deposited in the Naturalis Biodiversity Center, The Netherlands.

Extraction and Isolation. The sponge material (139 g dry weight after extraction) was chopped into small pieces and extracted by mixture of $1: 1 \mathrm{CH}_{2} \mathrm{Cl}_{2} / \mathrm{MeOH}(2 \times 1.5 \mathrm{~L}$, each $24 \mathrm{~h})$ to afforded $1.2 \mathrm{~g}$ of extract. The extract was separated by size exclusion chromatography on a Sephadex LH-20 column eluted with a mixture of 1:1 MeOH/ $\mathrm{CHCl}_{3}$ to afford 12 fractions. Fractions 9-12 (142 mg) were combined and separated on a Sephadex LH-20 column with MeOH as the eluent to afford 12 fractions. Fraction $10(33.0 \mathrm{mg})$ was separated by HPLC on a preparative RP- 8 column (YMC-Pack C- $8250 \times 20$ $\mathrm{mm}, 5 \mu \mathrm{m}, \mathrm{DAD}$ ) with a mixture of $45: 55 \mathrm{CH}_{3} \mathrm{CN} / \mathrm{H}_{2} \mathrm{O}$ to afford the three pure natural products, cyclotheonellazole A (1) (1.6 mg, retention time $\left(t_{\mathrm{R}}\right) 22.3 \mathrm{~min}, 0.0952 \%$ yield), cyclotheonellazole B (2)
(1.4 mg, $t_{\mathrm{R}} 25.5 \mathrm{~min}, 0.0833 \%$ yield), and cyclotheonellazole C (3) (1.2 mg, $t_{\mathrm{R}} 19.8 \mathrm{~min}, 0.0714 \%$ yield).

Cyclotheonellazole $A$ (1): amorphous, colorless material; $[\alpha]^{24}$ -20 (c 0.1, MeOH); UV (MeOH) $\lambda_{\max }(\log \varepsilon) 206$ (3.51) nm; IR (ATR Diamond) $\nu_{\max } 3381,1691,1658,1641,1631,1053,1033,699$ $\mathrm{cm}^{-1}$; NMR data, Table 1; HRESIMS $\mathrm{m} / z$ 1042.3029 $[\mathrm{M}+\mathrm{Na}]^{+}$ (calcd for $\mathrm{C}_{44} \mathrm{H}_{54} \mathrm{~N}_{9} \mathrm{Na}_{2} \mathrm{O}_{14} \mathrm{~S}_{2}, 1042.3027$ ); retention times of AAdinitrophenyl alanine amide (DAA) derivatives: L-Ala-L-DAA, 11.58 min, L-Ala-D-DAA, 11.37 min; L-Dpr-L-DAA, $20.58 \mathrm{~min}$, L-Dpr-D-DAA, $20.20 \mathrm{~min}$; L-Apa-L-DAA, $15.72 \mathrm{~min}$, L-Apa-D-DAA, $18.16 \mathrm{~min}$; L-Ile-LDAA, $17.93 \mathrm{~min}$, L-Ile-D-DAA, $20.28 \mathrm{~min}$; L-Ptt-L-DAA, $16.29 \mathrm{~min}$, LPtt-D-DAA, 16.31 min; L-Cya-L-DAA, 13.37 min, L-Cya-D-DAA, 12.46 $\min$.

Cyclotheonellazole B (2): amorphous, colorless material; $[\alpha]^{24}$ -45 (c 0.05, MeOH); UV (MeOH) $\lambda_{\max }(\log \varepsilon) 259$ (3.44) nm; IR (ATR Diamond) $\nu_{\max } 3292,2963,2931,1716,1670,1576,1558,1206$, 1139, 1046, 826, 803, 769, $740 \mathrm{~cm}^{-1}$; NMR data, Tables 2 and S1; HRESIMS $m / z 1034.3363[\mathrm{M}+\mathrm{H}]^{+}$(calcd for $\mathrm{C}_{45} \mathrm{H}_{57} \mathrm{~N}_{9} \mathrm{NaO}_{14} \mathrm{~S}_{2}$, 1034.3364); retention times of DAA derivatives: L-Ala-L-DAA, 11.72 min; L-Dpr-L-DAA, 20.55 min; L-Leu-L-DAA, $17.61 \mathrm{~min}$, D-Leu-L-DAA, $17.74 \mathrm{~min}$; L-Ile-L-DAA, $18.00 \mathrm{~min}$; L-Ptt-L-DAA, $16.26 \mathrm{~min}$; L-Cya-LDAA, $13.51 \mathrm{~min}$.

Cyclotheonellazole C (3): amorphous, colorless material; $[\alpha]^{23}$ -11 ( c 0.2, MeOH); UV (MeOH) $\lambda_{\max }(\log \varepsilon) 207(4.15) \mathrm{nm}$; IR (ATR Diamond) $\nu_{\max } 3321,2917,2849,1658,1546,1515,1207,1044$, $699 \mathrm{~cm}^{-1}$; NMR data, Tables 2 and S2; HRESIMS $\mathrm{m} / z$ 1028.2869 [M $+\mathrm{Na}]^{+}$, (calcd for $\left.\mathrm{C}_{43} \mathrm{H}_{52} \mathrm{~N}_{9} \mathrm{Na}_{2} \mathrm{O}_{14} \mathrm{~S}_{2}, 1028.2871\right)$; retention times of DAA derivatives: L-Ala-L-DAA, $11.10 \mathrm{~min}$; L-Dpr-L-DAA, 20.59 min; LhomoAla-L-DAA, $12.28 \mathrm{~min}$, D-homoAla-L-DAA, $12.30 \mathrm{~min}$; L-Ile-LDAA, $17.88 \mathrm{~min}$; L-Ptt-L-DAA, $16.28 \mathrm{~min}$.

Methods for Determination of the Absolute Configurations. To determine the absolute configuration of the amino acids, advanced Marfey's analysis was performed. A sample of $0.25 \mathrm{mg}$ of compounds 1-3 was treated with $\mathrm{H}_{2} \mathrm{O}_{2} / \mathrm{NaOH}(2 \mathrm{~h})$ followed by acid hydrolysis, enabling recovery of Ile from the Amoha moiety and the rest of the free amino acids. The hydrolysis of $\mathbf{1 - 3}$ was carried out at $104{ }^{\circ} \mathrm{C}$ for $60 \mathrm{~min}$ with $500 \mu \mathrm{L}$ of $6 \mathrm{M} \mathrm{HCl}$. The solution of 1 was divided into two portions, which were dried under vacuum to afford the dry mixture of amino acids, and the residue was dissolved in $100 \mu \mathrm{L}$ of $\mathrm{H}_{2} \mathrm{O}$. One portion was derivatized with L-FDAA and the other with DFDAA. The hydrolysates of $\mathbf{2}$ and $\mathbf{3}$ were evaporated to dryness, and the residues were dissolved in $100 \mu \mathrm{L}$ of $\mathrm{H}_{2} \mathrm{O}$. Similar solutions were prepared from the reference amino acids $\mathrm{D} / \mathrm{L}-\mathrm{Leu}$ and $\mathrm{D} / \mathrm{L}-$ homoalanine. To the latter solution were added $20 \mu \mathrm{L}$ of $1 \mathrm{M}$ sodium bicarbonate, per each amino acid in the peptide, followed by Lor D-FDAA $\left(30.5 \times 10^{-6} \mathrm{~mol} / \mathrm{L}\right.$ in acetone $)$ at a molar ratio of $1: 1.2$ for each amino acid. These solutions were stirred at $40^{\circ} \mathrm{C}$ for $60 \mathrm{~min}$. The reactions were quenched by the addition of $20 \mu \mathrm{L}$ of $2 \mathrm{~N} \mathrm{HCl}$ for each amino acid. The solutions were evaporated and dissolved in 250 $\mu \mathrm{L}$ of $\mathrm{CH}_{3} \mathrm{CN}$. The two samples of $\mathrm{L}$ - and D-FDAA derivatives were analyzed by ESI LCMS. The analysis was performed on an AcquityUPLC (Waters Inc., USA) coupled with a UV detector (Acquity-TUV detector, Waters Inc.) and mass spectrometer (Xevo TQD, Waters Inc.) The stationary phase consisted of a C18 $(1.7 \mu \mathrm{m}, 2.1 \times 100 \mathrm{~mm})$ column (Waters Inc.), and the mobile phase compositions were $\mathrm{A}$ : 95:5 $\mathrm{H}_{2} \mathrm{O} / \mathrm{CH}_{3} \mathrm{CN}+0.1 \%$ formic acid (FA) and $\mathrm{B}: \mathrm{CH}_{3} \mathrm{CN}+0.1 \%$ FA. The elution gradient was as follows: starting conditions $1 \mathrm{~min}$ of $100 \% \mathrm{~A}$, linear gradient to $40 \% \mathrm{~B}$ over $25 \mathrm{~min}$, and hold for $4 \mathrm{~min}$. Samples of $10 \mu \mathrm{L}$ were injected, and the flow rate was $0.5 \mathrm{~mL} / \mathrm{min}$. The UV detector was set to $340 \mathrm{~nm}$, while the mass spectrometer was operated in both negative and positive ion modes, scanning between 200 and 650 mass units. The interpretation of the data was conducted after the run on both positive and negative ion modes by MassLynx software (v4.1, Waters Laboratory Informatics).

In Vitro Antiplasmodial Assays. The P. falciparum strains utilized and details of the assay protocols have been previously reported. ${ }^{24}$ The selectivity index was determined as the ratio of cytotoxicity over antiplasmodial activity (expressed in $\mathrm{IC}_{50}$ values).

Protease Inhibition Assays. The samples for biological assays were dissolved in DMSO at a concentration of $1 \mathrm{mg} / \mathrm{mL}$, and the $\mathrm{IC}_{50}$ 
values were determined by series dilutions that produced a sigmoidshaped response pattern of the enzyme inhibition versus the concentration of the inhibitor, according to the four-parameter logistic model. ${ }^{25}$ The assays were made in 96-well plates for the following enzymes.

Chymotrypsin. The assay was performed in a Tris buffer $(0.6 \mathrm{~g}$ TRIS $\mathrm{HCl} / 100 \mathrm{~mL} \mathrm{H}_{2} \mathrm{O}, \mathrm{pH} 7.5$ ). The enzyme and the substrate SucGly-Gly-phenylalanine- $p$-nitroanilide were dissolved in the buffer at a concentration of $1 \mathrm{mg} / \mathrm{mL}$. To each well were added $100 \mu \mathrm{L}$ of buffer, $10 \mu \mathrm{L}$ of enzyme, and $10 \mu \mathrm{L}$ of sample. Then, the plate was placed in the spectrophotometer for $5 \mathrm{~min}$ of incubation at $37^{\circ} \mathrm{C}$. Thereafter, to each well was added $100 \mu \mathrm{L}$ of substrate solution, and the plate was replaced in the spectrophotometer for the kinetic measurement of the absorbance intensity over $30 \mathrm{~min}$ at a wavelength of $405 \mathrm{~nm}$.

Elastase. The assay was performed in a Tris buffer $(2.422 \mathrm{~g}$ TRIS $\mathrm{HCl} / 100 \mathrm{~mL} \mathrm{H}_{2} \mathrm{O}, \mathrm{pH} 8.0$ ). The enzyme and the substrate, $N$-SucAla-Ala-Ala- $p$-nitroanilide, were dissolved in the buffer at a concentration of 75 and $0.9 \mathrm{mg} / \mathrm{mL}$, respectively. A $150 \mu \mathrm{L}$ amount of buffer solution, $10 \mu \mathrm{L}$ of enzyme, and $10 \mu \mathrm{L}$ of sample were added to each well. Then, the plate was placed in the spectrophotometer for 20 min of incubation at $30^{\circ} \mathrm{C}$. Thereafter, $30 \mu \mathrm{L}$ of substrate solution was added to each well, and the plate was replaced in the spectrophotometer for the kinetic measurement of the absorbance intensity over $20 \mathrm{~min}$ at a wavelength of $405 \mathrm{~nm}$.

\section{ASSOCIATED CONTENT}

\section{S Supporting Information}

The Supporting Information is available free of charge on the ACS Publications website at DOI: 10.1021/acs.jnatprod. 7 b00028.

Spectroscopic data including 1D and 2D NMR spectra and HRMS data of compounds 1-3 and complete 2D NMR data of compounds 2 and 3 (PDF)

\section{AUTHOR INFORMATION}

\section{Corresponding Author}

*Tel (S. Carmeli): +972-3-6408550. Fax: +972-3-6409293. Email: carmeli@pot.tau.ac.il.

\section{ORCID ${ }^{\circ}$}

Alisson Ledoux: 0000-0002-4052-6336

Shmuel Carmeli: 0000-0002-9641-9943

\section{Notes}

The authors declare no competing financial interest.

\section{ACKNOWLEDGMENTS}

The authors express their gratitude to M. E. Remanevy for assistance in sponge collection; Y. Abudi for technical assistance; and N. Tal, the Mass Spectrometry Facility of the School of Chemistry, Tel Aviv University, for the measurements of the mass spectra. The present research was supported in part by a Tel Aviv University internal grant (S.C. and Y.K.). M.I. acknowledges the Ph.D. Fellowship from the School of Chemistry of Tel Aviv University. M.A., A.G.-B., and M.F. gratefully acknowledge financial support from the European Commission and the Regional Council of Reunion Island: BIOMOL-TCN program (Activités Thérapeutiques, Cosmétologiques et Nutraceutiques de Molécules Issues de la Biodiversité Terrestre, Marine et Microbienne de la Zone Sud-Ouest de l'Océan Indien), ERDF (European Regional Development Fund).

\section{REFERENCES}

(1) Carmely, S.; Kashman, Y. Tetrahedron Lett. 1985, 26, 511-514.
(2) Andrianasolo, E. H.; Gross, H.; Goeger, D.; Musafija-Girt, M.; McPhail, K.; Leal, R. M.; Mooberry, S. L.; Gerwick, W. H. Org. Lett. 2005, 7, 1375-1378.

(3) Nakao, Y.; Oku, N.; Matsunaga, S.; Fusetani, N. J. Nat. Prod. 1998, 61, 667-670.

(4) Chill, L.; Kashman, Y.; Schleyer, M. Tetrahedron 1997, 53, 16147-16152.

(5) Tsuda, M.; Ishiyama, H.; Masuko, K.; Takao, T.; Shimonishi, Y.; Kobayashi, J. Tetrahedron 1999, 55, 12543-12548.

(6) Festa, C.; De Marino, S.; Sepe, V.; Monti, M. C.; Luciano, P.; D’Auria, M. V.; Debitus, C.; Bucci, M.; Vellecco, V.; Zampella, A. Tetrahedron 2009, 65, 10424-10249.

(7) Hamada, T.; Matsunaga, S.; Fujiwara, M.; Fujita, K.; Hirota, H.; Schmicki, R.; Guntert, P.; Fusetani, N. J. Am. Chem. Soc. 2010, 132, 12941-12945.

(8) Fusetani, N.; Warabi, K.; Nogata, Y.; Nakao, Y.; Matsunaga, S. Tetrahedron Lett. 1999, 40, 4687-4690.

(9) Ueoka, R.; Ise, Y.; Ohtsuka, S.; Okada, S.; Yamori, T.; Matrsunaga, S. J. Am. Chem. Soc. 2010, 132, 17692-17694.

(10) Ratnayake, A. S.; Bugni, T. S.; Feng, X.; Harper, M. K.; Skalicky, J. J.; Mohammed, K. A.; Andjelic, C. D.; Barrows, L. R.; Ireland, C. M. J. Nat. Prod. 2006, 69, 1582-1586.

(11) Ford, P. W.; Gustafson, K. R.; McKee, T. C.; Shigematsu, N.; Maurizi, L. K.; Pannell, L. K.; Williams; de Silva, E. D.; Lassota, P.; Allen, T. M.; Soest, R. V.; Andersen, R. J.; Boyd, M. R. J. Am. Chem. Soc. 1999, 121, 5899-5909.

(12) Zampella, A.; D’Auria, M. V.; Paloma, L. G.; Casapullo, A.; Minale, L.; Debitus, C.; Henin, Y. J. Am. Chem. Soc. 1996, 118, 62026209.

(13) Gunasekera, S. P.; Pomponi, S. A.; McCarthy, P. J. J. Nat. Prod. 1994, 57, 79-83.

(14) Kimura, M.; Wakimoto, T.; Egami, Y.; Tan, K. C.; Ise, Y.; Abe, I. J. Nat. Prod. 2012, 75, 290-294.

(15) Wilson, M. C.; Mori, T.; Ruckert, C.; Uria, A. R.; Helf, M. J.; Takada, K.; Gernert, C.; Steffens, U. A. E.; Heycke, N.; Schmitt, S.; Rinke, C.; Helfrich, E. J. N.; Brachmann, A. O.; Gurgui, C.; Wakimoto, T.; Kracht, M.; Crusemann, M.; Hentschel, U.; Abe, I.; Matsunaga, S.; Kalinowski, J.; Takeyama, H.; Piel, J. Nature 2014, 506, 58-62.

(16) Fujii, K.; Ikai, Y.; Mayumi, T.; Oka, H.; Suzuki, M.; Harada, K. Anal. Chem. 1997, 69, 3346-3352.

(17) Kimura, M.; Wakimoto, T.; Egami, Y.; Tan, K. C.; Ise, Y.; Abe, I. J. Nat. Prod. 2012, 75, 290-294.

(18) Adiv, S.; Aharonov-Nadborny, R.; Carmeli, S. Tetrahedron 2010, 66, 7429-7436.

(19) Lifshits, M.; Carmeli, S. J. Nat. Prod. 2012, 75, 209-219.

(20) Elkobi-Peer, S.; Faigenbaum, R.; Carmeli, S. J. Nat. Prod. 2012, $75,2144-2151$.

(21) Marfey, P. Carlsberg Res. Commun. 1984, 49, 591-596.

(22) Lee, A. Y.; Hagihara, M.; Karmacharya, R.; Alberts, M. W.; Schreiber, L. S.; Clardy, J. J. Am. Chem. Soc. 1993, 115, 12619-12620.

(23) Maryanoff, B. E.; Costanzo, M. J. Bioorg. Med. Chem. 2008, 16, $1562-1595$

(24) Jansen, O.; Tits, M.; Angenot, L.; Nicolas, J. P.; De Mol, P.; Nikiema, J. B.; Frédérich, M. Malar. J. 2012, 11, 289.

(25) Sebaugh, J. L. Pharmaceut. Statist. 2011, 10, 128-134. 